\title{
Alcohol consumption in students of sixth grade of public primary school of Minatitlán, Veracruz
}

\section{Consumo de alcohol en estudiantes de sexto grado de primarias públicas de Minatitlán, Veracruz}

CORTAZA-RAMÍREZ, Leticia $\dagger^{*}$, VINALAY-CARRILLO, Ilsia, ALVARADO-CRUZ, Laura and LÓPEZ-AVENDAÑO, Rosa Armida

Universidad Veracruzana, Facultad de Enfermería Campus Minatitlán.

ID $1^{\text {st }}$ Author: Leticia, Cortaza-Ramírez / ORC ID: 0000-0002-0592-7695, Researcher ID Thomson: AAL-4015-2020, CVU CONACYT-ID: 252470

ID $1^{\text {st }}$ Coauthor: Ilsia, Vinalay-Carrillo / ORC ID: 0000-0002-63859598, CVU CONACYT-ID: 694648

ID $2^{\text {nd }}$ Coauthor: Laura, Alvarado-Cruz / ORC ID: 0000-0003-4372-0289

ID $3^{\text {rd }}$ Coauthor: Rosa A., López-Avendaño / ORC ID: 0000-0001-8937-1577

DOI: $10.35429 /$ EJS.2020.12.7.1.10

Received: January 30, 2020; Accepted: June 20, 2020

\section{Abstract}

This research is a descriptive and cross-sectional study, carried out with the objective of describing the prevalence of experimental alcohol consumption in sixth grade students of public primary schools in Minatitlán, Veracruz, Mexico. The population was 1,560 sixth grade students; the final sample was 388 students. A simple group and random sampling were used. To collect the information, a personal data card was used that investigated the age, sex, experimental alcohol consumption, the age of onset of first consumption, frequency, who provided the drink and alcohol consumption in the parents. The study adhered to the General Health Law regarding Research. The results show that the average age of onset of alcohol consumption was 8.7 years, $59.4 \%$ on boys and $40.6 \%$ on girls reported having consumed alcohol. The preferred drink to experience consumption was beer $(40.6 \%), 66.5 \%$ reported that their parents were aware of the consumption made and $61.8 \%$ indicated that both parents consumed alcohol. These results reveal that the children who participated in the study are starting consumption below the national average reported by the ENCODAT 2016-2017. Boys report higher consumption than girls, and participant's alcohol consumption is tolerated by parents

Consumption of alcoholic beverages, students, alcohol consumption in minors

\section{Resumen}

Investigación de tipo descriptivo y transversal, realizado con el objetivo de describir la prevalencia del consumo de alcohol experimental en estudiantes de sexto grado de primarias públicas de Minatitlán, Veracruz México. La población fueron 1560 estudiantes de sexto año de primaria, muestra final de 388 estudiantes. Se utilizó muestreo por conglomerados y aleatorio simple. Se utilizó una cédula de datos personales que indagó edad, sexo, consumo de alcohol experimental, edad de inicio del primer consumo, frecuencia, quién proporcionó la bebida y consumo de alcohol en los padres. El estudio se apegó a la Ley General de Salud en materia de Investigación. Los resultados muestran que la edad de inicio de consumo de alcohol, fue de 8.7 años, $59.4 \%$ de niños y $40.6 \%$ de niñas reportaron haber consumido alcohol. La bebida preferida para experimentar fue la cerveza $(40.6 \%), 66.5 \%$ refiere que sus padres tienen conocimiento del consumo, $61.8 \%$ indican que ambos padres consumen alcohol. Estos resultados revelan que los niños que participaron en el estudio están iniciando el consumo por debajo de la media nacional reportada por la ENCODAT 2016-2017. Los niños reportan mayor consumo que las niñas y el consumo de alcohol de los participantes es tolerado por los padres.

Consumo de bebidas alcohólicas, estudiantes, consumo de alcohol en menores

Citation: CORTAZA-RAMÍREZ, Leticia, VINALAY-CARRILLO, Ilsia, ALVARADO-CRUZ, Laura and LÓPEZ-AVENDAÑO, Rosa Armida. Alcohol consumption in students of sixth grade of public primary school of Minatitlán, Veracruz. ECORFAN Journal-Spain. 2020. 7-12: 1-10.

\footnotetext{
* Correspondence to Author (Email: leticortaza@ hotmail.com)

$\dagger$ Researcher contributing as first author.
} 


\section{Introduction}

Today, alcohol is one of the most widely used drugs in the world, its abuse is associated with innumerable negative consequences, becoming responsible for a high number of health problems. Currently, it is considered the most widely consumed legal drug that has formed part of man's social and cultural environment, which has made it a widely used substance with enormous social acceptance. Within this context, alcohol consumption in the adolescent population takes on special relevance since it is a reflection of adaptation to society, attributing a social meaning to the adult world at the beginning, in addition to giving the substance some appeal (Smoked, Gámez and Valdez, 2017).

Excessive consumption is considered a serious global public health problem, which is present in various age groups, however the young population, as indicated above, is the most sensitive both to consumption and its consequences, so It has become one of the problems of greatest concern in society, due to its increase and the consequences for the consumer, both in their health and in their relationship with those around them.

It is well known that the consumption of this substance has direct and indirect effects on health. However, young people tend to experiment with this type of high-risk activities despite knowing some of its possible consequences (Orellana, 2019).

It is important to highlight that the stage between the end of childhood and the beginning of adolescence is a vulnerable period for drug experimentation, so consumption in this phase represents an increasingly frequent problem, and specifically in the childhood, has become a public health problem in the last decade (De Lima et al, 2016).

Early alcohol consumption has been found associated with countless negative events such as car accidents, increased exposure to violence, unwanted pregnancies, as well as increased suicide risks; in addition to causing losses in brain development, it produces in those who begin consumption early, a greater risk of presenting psychic disorders.
It is important to mention that the availability and frequency of consumption by relatives, in some way predisposes the onset of early consumption by children and young people, noting that the majority of individuals who start drinking early, frequently observe the use of alcohol at home (De Lima et al, 2016).

It is also known that age modulates the role of different risk and protective factors, associated with a greater or lesser probability of alcohol use and abuse. Studies show that the effects of acute and chronic alcohol administration differ according to the stage of development in which the consumer is, with an impact on the health of young adolescents especially. Similarly, early onset has been found to be markedly associated with the appearance of problems due to alcohol consumption. This has led to an increase in the number of investigations focused on the initiation of alcohol consumption in children under 12 years of age, who are starting to use the substance at an earlier age (Duffy, 2014).

In this regard, studies carried out in Spain by the International Institute for Family Studies indicate that within the family, attitudes, habits and opinions of the family environment in everything related to alcohol and its consumption determine the child's perception and how you will position yourself in the future on this issue. It also indicates that a poor, distant or difficult relationship with their parents is correlated with the presence of high alcohol consumption during adolescence. It also points out that if the child gets used to seeing a high consumption of alcohol in the family environment or does not have a clear perception of the consequences on their intake, they become more vulnerable to consuming alcohol prematurely (The Family Watch, 2017). Likewise, Ahumada, Gámez and Valdez in 2017, mention that from birth the learning and socialization processes present during the development of the human being influence through the learning of socially accepted norms and behaviors in family, school, friends / peers and the media. They indicate that the family plays a crucial role in protecting the child from drug use, since the family is the first social environment in which the individual develops and behaviors are modeled, it has a structure, organization, hierarchy and patterns of interaction. social that condition the behavior of its members. 
However, this same family that protects, can also be considered a risk factor for starting consumption, because if there is consumption in it, it is the behavior patterns that the child tends to normalize. In this regard, Rojas, Rodríguez Zereceda and Otiniano (2013), affirm that family is a vital factor in approaching alcohol consumption.

Regarding their social environment, young adolescents need to connect with the peer group, which also represents a source of models and reinforcement of experimental behaviors. The peer group may pressure, or the individual may feel pressured towards the practice of risky behaviors; even turn them into identity signs, and it is at this stage that the boy or girl is willing to transgress and experience new sensations, and where both drugs and alcohol can act as a form of group membership. It is a moment of risk, and for some a way out of the prevailing social model.

Likewise, the multiple alternatives on the market for consuming, relating and having fun, favor risk situations, considering that these would be other reasons why minors consume alcohol. Eating in minors is mainly a way of fun, which has left healthy and constructive leisure in the background, such as practicing sports or carrying out cultural activities (Defensor del Menor de Andalucía, 2017).

In this regard, a study carried out in Spain by The Family Watch, (2017), indicates that $25 \%$ of the participants started consuming before the age of 13 and $50 \%$ before the age of 15 ; The findings reported events with devastating consequences related to the abusive consumption of alcohol at very young ages, which has fueled the social debate on this problem and has underlined the need to take sanitary and social measures in the face of this health problem in this country.

Another study carried out in England, with children between 11 and 14 years of age ( $n$ $=3,641$ ), showed that $45.5 \%$ of these little ones had already drunk on occasion, having a mean age of experiencing alcohol of 9.4 years in girls and 10 years in boys (Philips, et al, 2010).
In Latin America, the consumption of alcoholic beverages is a constant concern for specialists and authorities, statistical data show disturbing changes in the habits of adolescents regarding the consumption of this type of beverage, pointing out that legal substances are the ones that they are consumed earlier, with an approximate onset between 10 and 14 years old, and early consumption impacts alcohol use behavior and problems related to this drug (Duffy, 2014).

In this regard, the Report on drug use in the Americas, carried out by the Organization of American States (OAS) and the Inter-American Commission for the Control of Drug Abuse (CICAD) in 2019, indicates that the prevalence of drug use in the last month of alcoholic beverages in the general population, shows a wide range of different consumption ranges, ranging from $9.5 \%$ in El Salvador to more than $52 \%$ in Argentina and Uruguay, followed by the United States with a consumption of $50 \%$ and from The Bahamas, Chile and Paraguay that exceed $40 \%$.

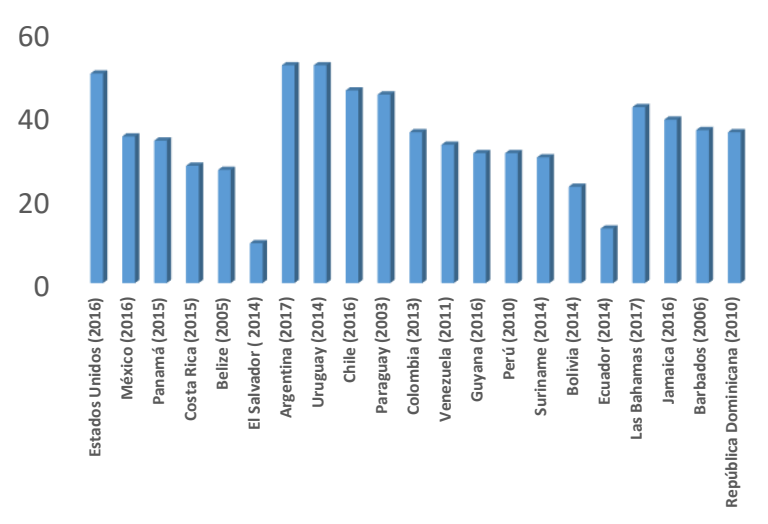

Figure 1 Prevalence of the last month of alcohol consumption in the general population by country, ordered by subregion

Source: Taken from the Report on drug use in the Americas 2019. OAS / CICAD

Data from the survey carried out by the National Commission for Development and Life without Drugs in Peru 2013, mention that the family environment that includes parents and siblings (19.4\%), cousins and uncles (17.1\%), represent the main starting environment consumption of alcoholic beverages (36.5\%), followed by friends from the neighborhood $(24.3 \%)$ and fellow students $(23.8 \%)$. Regarding the annual incidence rate of alcohol, the study determined that each year more than 230,000 schoolchildren start consuming alcoholic beverages in this country. 
Similarly, a study carried out in southern Brazil highlights that the use of alcohol throughout life was present in $62.8 \%$ of the participants, who indicated that they had already had some contact with alcohol and 12.8\% claimed to have drunk before the age of 10 , 45.3\% had some type of contact with alcohol in the last month, regarding sex, $48.7 \%$ of the boys and $42.7 \%$ of the girls consumed alcohol in the last 30 days. The prevalence of alcohol consumption in the last month increased according to age, those who were 10 years old $3.2 \%$ had drunk in the last 30 days; those who were 11 years old $6.4 \%$, those who were 12 years old $30.4 \%$ and those who were 13 years old $60 \%$ (De Lima et al, 2016).

In Argentina, Grigoravicius et al (2013), in their study of children, indicated that of the total number of children who ever consumed alcohol, 53\% did so in the last year, the most consumed drink was cider and beer. Of the total number of children who had drunk, $69 \%$ did so in the last year and 5\% drank in the last 30 days prior to administration of the instrument.

Another investigation carried out in Argentina with the purpose of knowing the risk and protective factors associated with alcohol consumption in 348 children and adolescents, with an age range of between 8 and 14 years; found that $42.5 \%$ had ingested alcohol at some time in life, with a higher percentage in men $(48.3 \%)$ than in women $(36.8 \%)$. This same study indicates the need to carry out research in pre-puberty and puberty, since it is at this stage that a relationship between the initial pattern of consumption and excessive intake in adulthood begins to be established (Duffy, 2014).

Cabuya in 2013, carried out a study in Bogotá, Colombia, with children from 10 to 12 years old to know the prevalence of alcohol consumption, their results indicate that consumption was higher in girls than in boys, the educational level in which there is The highest consumption is in the sixth grade, and the age at which they start consuming alcohol is 10 years old.

Age of onset of alcohol consumption is considered a risk factor for subsequent alcohol abuse and dependence.
That is, the probability that there is an alcohol dependence increases by four, when consumption has started before the age of 14 , compared to those who start at 20 years of age. The highest risk is found in cases in which the onset occurs before 12 years of age, being higher in males (The Family Watch, (2017).

In Mexico, various investigations have reported the occurrence of experimental consumption in children of primary education, such as the one carried out in Celaya, Guanajuato, with 39 children of the first grade of primary education, aged 6 and 7, it was identified that $30.6 \%$ He had already had a beer sometime in his life. These types of findings demand preventive actions directed at school children (Hernández, et al 2017).

In this regard, Villatoro, et al. (2016), investigated the prevalence of drug, alcohol and tobacco use in elementary students (5th and 6th) and secondary-high school in Mexico and its States, reported that from a sample of 52,171 students in 5th and 6th grades In primary school, the prevalence "sometime in life" is $16.9 \%$, $21.5 \%$ in men and $12.1 \%$ in women. Alcohol consumption in the last year was $8.1 \%(10.5 \%$ men and $5.5 \%$ women). In excessive consumption, $2.4 \%$ mentioned that in the last month they had consumed five or more glasses on one occasion (3.3\% men, $1.4 \%$ women). It highlights that $12.5 \%$ of those who have not consumed alcohol indicate that they will probably consume it and $22.6 \%$ of those who have already consumed it would do so again.

As can be seen from the above, alcohol consumption in children represents a constant health problem, and it is because of this that the present study was conducted with the aim of describing the prevalence of experimental alcohol consumption in sixth-grade students. public primary grade of Minatitlán, Veracruz Mexico. In order to implement intervention strategies in this population group, to reduce the approach of these children to the consumption of alcoholic beverages.

\section{Methodology}

Descriptive and cross-sectional study carried out on a population of 1,560 sixth grade students from 52 public primary schools in the municipality of Minatitlán, Veracruz, Mexico. 
The sample was made up of 388 students The sampling used was by clusters and the selection of schoolchildren was simple random; Students enrolled in the August 2018 - January 2019 school period participated.

\section{Instruments}

To collect the data, a sociodemographic data card prepared by the study authors was used. Questions were asked to find out the prevalence of experimental alcohol consumption, where the age of first consumption, frequency, who had provided the alcohol, as well as consumption in parents and other relatives.

\section{Ethical considerations and procedure}

In the ethical aspect, the research adhered to the provisions of the General Law of Mexican Health, in the Matter of Research for Health 2014. The study was authorized by the Ethics and Research Committee of the Faculty of Nursing of Minatitlán with protocol number CIEE-SM-154. The information from the schools was requested from the City Council of the municipality of Minatitlán, through a letter issued by the direction of the Faculty of Nursing.

Once the information was obtained, 12 schools were randomly chosen to make up the sample, and each of the selected institutions was subsequently contacted to request permission from the educational authorities. After authorization, the participants were selected and the sociodemographic data card and the questions related to alcohol consumption were applied, after giving the consent and informed consent to each student. To avoid confusion in children, data collection was performed by reading each item aloud, in this way all students responded at the same time, according to what the authors Pilatti, Gody and Brussino (2010) indicated, who indicate which is a recommended technique. Once the data collection was completed, the information capture and analysis was performed using the SPSS version 24.0 program for Windows.

\section{Results}

The findings of this research carried out on 388 sixth grade students, show that the age of the participants was between 10 and 12 years old, with a mean of 10.84 years $(S D=0.46)$.
Regarding alcohol consumption, the majority (54.63\%) indicated having experimentally consumed an alcoholic beverage, with a predominance of males (59.4\%).

Table 1 shows that, of the children who indicated having consumed alcoholic beverages, $75 \%$ mentioned professing a religion and $73.6 \%$ practicing a sport; both actions considered as protective factors for the consumption of alcoholic beverages; In this sense, in the studied group the behavior of these variables was different from that reported by other investigations, since consumption prevailed in children who profess a religion or who practice sports.

\begin{tabular}{|c|c|c|c|c|}
\hline & \multicolumn{2}{|c|}{ Consumers } & \multicolumn{2}{|c|}{ No Consumers } \\
\hline & $f$ & $\%$ & $f$ & \\
\hline \multicolumn{5}{|l|}{ Sex } \\
\hline Male & 126 & 59.4 & 78 & 44.3 \\
\hline Female & 86 & 40.6 & 98 & 55.7 \\
\hline \multicolumn{5}{|l|}{ Age } \\
\hline 10 years & 40 & 18.9 & 37 & 21 \\
\hline 11 years & 164 & 77.4 & 132 & 75 \\
\hline 12 years & 8 & 3.8 & 7 & 4 \\
\hline \multicolumn{5}{|l|}{ Religion } \\
\hline Catholic & 114 & 53.8 & 72 & 40.9 \\
\hline Christian & 37 & 17.5 & 40 & 22.7 \\
\hline Other & 8 & 3.8 & 11 & 6.3 \\
\hline None & 53 & 25.0 & 53 & 30.1 \\
\hline \multicolumn{5}{|l|}{ Do you play any sport } \\
\hline Yes & 156 & 73.6 & 104 & 59.1 \\
\hline No & 56 & 26.4 & 72 & 40.9 \\
\hline
\end{tabular}

Table 1 Alcohol consumption and sociodemographic data of sixth grade students

Source: own elaboration from the Sociodemographic Data Certificate

Regarding the age at which they indicate having started experimenting with alcoholic beverages, this was between 6 and 12 years of age, an average of 8.7 years (Table 2 ).

In the students who reported having consumed an alcoholic drink on an experimental basis, $74.1 \%$ reported having consumed it in the last year, $18.8 \%$ had consumed it in the last month and $7.1 \%$ ingested alcoholic beverages in the last week prior to the study; worrying fact, since all the participants are under 12 years old (Table 3). 


\begin{tabular}{|l|r|r|}
\hline Age & \multicolumn{1}{|c|}{$\boldsymbol{f}$} & \multicolumn{1}{c|}{$\boldsymbol{1}$} \\
\hline 6 years & 30 & 14.2 \\
\hline 7 years & 26 & 12.3 \\
\hline 8 years & 32 & 15.1 \\
\hline 9 years & 26 & 12.3 \\
\hline 10 years & 78 & 36.8 \\
\hline 11 years & 18 & 8.5 \\
\hline 12 years & 2 & 0.8 \\
\hline
\end{tabular}

Table 2 Age of onset of alcohol consumption Source: own elaboration from the Sociodemographic Data Certificate

\begin{tabular}{|l|r|r|}
\hline Frequency of consumption & \multicolumn{2}{|c|}{ Consumers } \\
& \multicolumn{1}{|l|}{$f$} & $\%$ \\
\hline Consumption in the last year & 157 & 74.1 \\
\hline Consumption in the last month & 40 & 18.8 \\
\hline Consumption in the week & 15 & 7.1 \\
\hline
\end{tabular}

Table 3 Alcohol consumption in sixth grade students Source: own elaboration from the Sociodemographic Data Certificate

\begin{tabular}{|l|r|r|}
\multicolumn{2}{|c}{} & \multicolumn{2}{c|}{ Consumers } \\
\cline { 2 - 3 } & $f$ & \multicolumn{1}{c|}{$\%$} \\
\hline Drinking drink & & \\
\hline Beer & 86 & 40.6 \\
\hline Tequila & 5 & 2.4 \\
\hline Came & 45 & 21.2 \\
\hline Vodka & 7 & 3.3 \\
\hline Other & 28 & 13.2 \\
\hline More than 1 & 41 & 19.3 \\
\hline Who provides the drink & & \\
\hline Family & 176 & 83 \\
\hline Friend & 25 & 11.8 \\
\hline Own initiative & 11 & 5.2 \\
\hline
\end{tabular}

Table 4 Most consumed drink and who provided the drink Source: own elaboration from the Sociodemographic Data Certificate

Regarding the drink with the highest consumption (Table 4), it was found that beer $(40.6 \%)$ and wine $(21.2 \%)$ were preferred by students to experiment with alcohol. When asked about who the person who provided the drink was, they refer to relatives $(83.0 \%)$ as the people who in most cases facilitated consumption, in the same way they refer friends $(11.8 \%)$ as providers of the substance; however, $5.2 \%$ indicate that they made the consumption on their own initiative, results that show how the family and friends environment continues to be an incentive context for consuming alcohol.
Table 5 shows alcohol consumption and some data on the relationship of students with their family environment; the findings indicate that $61.8 \%$ of consumers come from a nuclear family and the majority perceive a good relationship with their parents $(56.6 \%)$; In the case of non-consumers, belonging to a nuclear family $(70.5 \%)$ and good perception of the relationship $(70.5 \%)$ with parents prevailed in the same way, both percentages are higher in those who do not consume.

It was also investigated, if their parents were aware that they had or consume alcoholic beverages, indicating $66.5 \%$ that their parents know that they consume, data that indicates the tolerance and permissiveness of parents towards this behavior.

In relation to the consumption of alcohol in the family environment of the students, $71.4 \%$ reported that alcoholic beverages are consumed in their family, prevailing consumption in parents (44.8\%) and uncles (28.9\%), also indicating that parties $(50.5 \%)$ and weekends $(24.3 \%)$ are the occasions where alcoholic beverages are ingested, it is worth mentioning that $3.2 \%$ report having family members who consume them daily (Table 6).

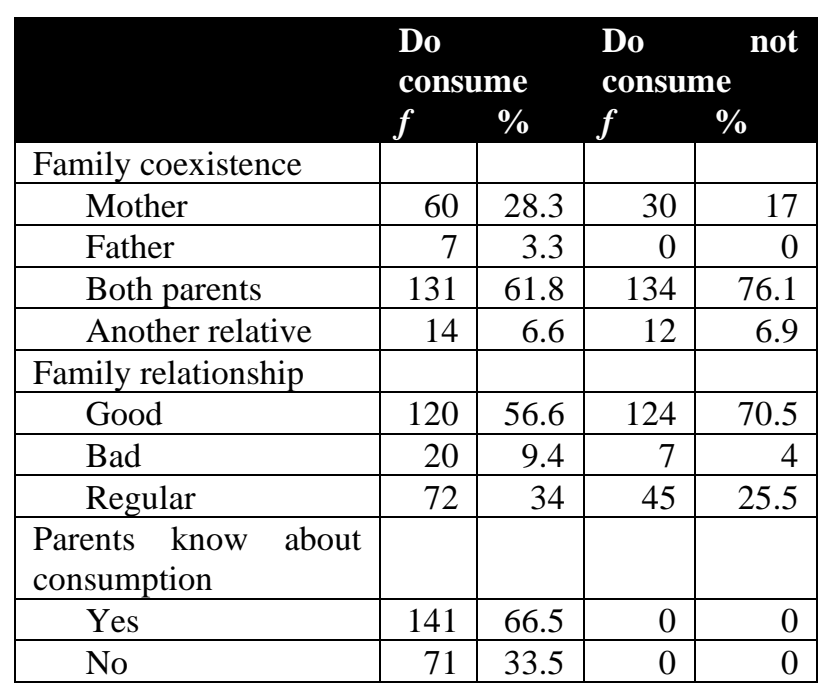

Table 5 Alcohol consumption and family relationship of students

Source: own elaboration from the Sociodemographic Data Certificate 


\begin{tabular}{|l|r|r|}
\hline & \multicolumn{1}{|c|}{$\boldsymbol{f} \%$} \\
\hline The family consumes alcohol & & \\
\hline Yes & 277 & 71.4 \\
\hline No & 11 & 28.6 \\
\hline Consuming family member & & \\
\hline Parents & 124 & 44.8 \\
\hline Uncles & 80 & 28.9 \\
\hline More than 1 family member & 38 & 13.7 \\
\hline Another relative & 35 & 12.6 \\
\hline Place of consumption & & \\
\hline Parties & 140 & 50.5 \\
\hline Convivios & 61 & 22 \\
\hline Weekends & 67 & 24.3 \\
\hline Daily & 9 & 3.2 \\
\hline
\end{tabular}

Table 6 Alcohol consumption in the family environment of the students

Source: own elaboration from the Sociodemographic Data Certificate

Regarding the social environment (Table 7), it is observed that $23.7 \%$ report having friends who consume alcohol and mention that parties $(55.4 \%)$ are the preferred place to consume, $12.3 \%$ indicate that their friends have offered alcohol and $8 \%$ have accepted the invitation, pointing out that the main reason that led them to accept consumption has been curiosity $(75 \%)$.

\begin{tabular}{|l|l|l|}
\hline \multicolumn{1}{|l|}{$\boldsymbol{f}$} & $\%$ \\
\hline Friends consume alcohol & & \\
\hline Yes & 92 & 23.7 \\
\hline No & 296 & 76.3 \\
\hline Situations in which they consume & & \\
\hline Parties & 51 & 55.4 \\
\hline Convivios & 21 & 22.8 \\
\hline Weekends & 18 & 19.6 \\
\hline Daily & 2 & 2.2 \\
\hline Offering alcohol by friends & & \\
\hline Yes & 48 & 12.3 \\
\hline No & 340 & 87.7 \\
\hline I agree & & \\
\hline Yes & 31 & 8.0 \\
\hline No & 357 & 92.0 \\
\hline Reason & & \\
\hline Out of curiosity & 24 & 75.0 \\
\hline So as not to lose my friends & 2 & 6.3 \\
\hline Because I like to consume it & 6 & 18.7 \\
\hline
\end{tabular}

Table 7 Alcohol consumption in the social environment of the students

Source: own elaboration from the Sociodemographic Data Certificate

\section{Discussion}

The present work was oriented to know the experimental alcohol consumption in sixth grade students of primary education of the City of Minatitlán in the south of the State of Veracruz. The results show that the average age of experimental start of consumption was found at 8.7 years of age, and more than half of the participants had already had their first experience with any alcoholic beverage, a data that coincides with the study carried out in Brazil. by De Lima in 2016, who reports an average age in the consumption experiment of 9.4 years in girls and 10 years in boys. Likewise, this result is below the national average reported by ENCODAT 2016-2017.

With regard to sex, among the consuming participants, consumption prevailed in men, similar data to the research by Villatoro in 2016 and Duffy in 2014 and Ocaña et al 2019, who indicate in their results a higher consumption of alcohol in men. Regarding the preferred drink, beer was the one with the highest consumption, a figure that differs from the study by Grigovaricius et al, (2013), who reports that in his study group cider was the most consumed drink; However, it coincides with Gerónimo, et al, 2017, who reports in the same way, that the most consumed drink was beer, and this was provided by a member of the family.

In this research, consumption seems to be tolerated by parents, since more than half of the parents of these students know about their children's consumption, a similar figure to the study by Grigovaricius et al, (2013) and Gerónimo, et al, (2017), referring that when consuming the research participants, they were in the presence of the adults responsible for their care, and even in many of the cases, the offer of alcohol came from their family. Likewise, this result coincides with Duffy's study in 2014, where it reports that the beginning of alcohol consumption occurs in the participants' homes, where it is adults who offer them to drink alcohol. Regarding consumption in the family environment, the study shows parents and close relatives as the main consumers, a finding similar to the study by Florenzano et al (2016), where it indicates that in more than half of the cases the main drinker was the father, mother or paternal or maternal figure, as well as other close relatives. 
Among the reasons that the participants refer to encouraged them to consume alcohol, there is curiosity to experiment with the substance, a result that also coincides with Duffy (2014), who reports that it is the curiosity to consume something prohibited and representative of the adult world. who has motivated drinking alcohol for the first time.

\section{Conclusion}

The present work shows that the majority of the children who participated in this research consume alcoholic beverages; Although this consumption is on an experimental basis, it seems that they approach this licit drug easily, with the consent of parents and relatives, an action that places them as a high-risk population so that consumption takes root in them, due to that the substance is present both in their family and social environment, leading them to reduce the risk that alcohol consumption represents for their health due to the lack of clear perception regarding consumption, due to their young age and daily contact with alcoholic beverages.

These results show the need to deepen research in this population group, to address this health problem from a preventive perspective. Therefore, the findings of this study give the guideline for the design of interventions that address consumption in school-age children, to educate on the consequences of alcohol consumption and try to reduce early onset.

\section{Financing}

There was financial support from the Program for Professional Teaching Development (PRODEP), project 29268 UV-CA-473

\section{References}

Ahumada Cortez, J. G., Gámez Medina, M. E. y Valdez Montero, C. (2017). El consumo de alcohol como problema de salud pública. $R a$ Ximhai, 13(2), 13-24. Recuperado de http://www.redalyc.org/articulo.oa?id=4615451 0001
Cabuya Moreno, D. M. (2013). Edad De Inicio, Caracterización Sociodemográfica y Consumo de SPA Licitas (Alcohol y Tabaco) en un Grupo de Estudiantes de un Colegio Privado de la Ciudad de Bogotá. Pontificia Universidad Javeriana. Colombia. Recuperado de https://repository.javeriana.edu.co/bitstream/ha ndle/10554/13789/CabuyaMorenoDianaMarcel a2013.pdf; jsessionid=AA63589D19A324FB64 BFC0687E8BB6A4? sequence=1

Comisión Interamericana para el Control del Abuso de Drogas. (2019). Informe sobre el consumo de drogas en las Américas. Recuperado de http://www.cicad.oas.org/main/pubs/Informe\% 20 sobre $\% 20$ el $\% 20$ consumo $\% 20$ de $\% 20$ drogas $\%$ 20en\%201as\%20Am\%C3\%A9ricas\%202019.pd $\mathrm{f}$

Comisión Nacional contra las Adicciones. (2017). Encuesta Nacional de Consumo de Drogas, Alcohol y Tabaco (ENCODAT) 20162017. Recuperado de https://www.gob.mx/salud\%7Cconadic/accione s-y-programas/encuesta-nacional-de-consumode-drogas-alcohol-y-tabaco-2016-2017-136758.

Comisión Nacional para el Desarrollo y Vida sin Drogas. (2013). I Encuesta nacional, Consumo de Drogas. (4305) Recuperado de http://www.codajic.org/sites/www.codajic.org/f iles/I_ENCUESTA_NACIONAL_CONSUMO _DE_DROGAS_INFRACTORES.pdf

De Lima Argimon, I. I., Campana, A., Estefenon, S., Bulcão Terroso, L. y Fernández López, R. M. (2016). Consumo de alcohol en niños y adolescentes de un municipio en el sur de Brasil. Argentina de Clínica Psicológica, 15(3), 267-274. Recuperado de https://www.redalyc.org/articulo.oa?Id=2819/2 81948416006

Defensor del Menor de Andalucía. (2017). Consumo de alcohol en menores. España. Recuperado de https://www.defensordelpuebloandaluz.es/sites/ default/files/estudio-alcohol-menores.pdf

Duffy, D. (2014). Consumo de alcohol en niños y adolescentes de 8 a 14 años. Factores y percepciones asociadas. En Psiencia. Latinoamericana de ciencia psicológica, 6(1), 110. Recuperado de https://dialnet.unirioja.es/descarga/articulo/489 3291.pdf

CORTAZA-RAMÍREZ, Leticia，VINALAY-CARRILLO, Ilsia, ALVARADO-CRUZ, Laura and LÓPEZ-AVENDAÑO, Rosa Armida. Alcohol consumption in students of sixth grade of public primary school of Minatitlán, Veracruz. ECORFAN Journal-Spain. 2020 
Florenzano, R., Echeverria, A., Sieverson, C., Barr, M. y Fernández, M. A. (2016). Daño a niños y sus familias por el consumo de alcohol: resultados de una encuesta poblacional. Revista Chilena Pediatrica, 87(3), 162-168. Recuperado de https://www.elsevier.es/es-revista-revistachilena-pediatria-219-pdf-S0370410615001795

Gerónimo Carrillo, R., Ramos Rendón, K. C., Rivas Acuña, V., Hernández Ramírez, G. y Mateo Crisóstomo, Y. (2017). Expectativas hacia el consumo de alcohol en niños escolares entre 8 y 12 años: estudio descriptivo. Medwave, 17(8). Recuperado de https://www.medwave.cl/link.cgi/Medwave/Est udios/Investigacion/7049.act

Grigoravicius, M., Bradichansky, L., Nigro, V., García Poultier, J., Iglesias, A. y Ponce, P. (2013). Consumo de alcohol en niños y niñas escolarizados entre 8 y 12 años. Comparación de resultados entre una población clínica y una población no clínica. En Anuario de Investigaciones. XX, 311-320. Recuperado de https://www.redalyc.org/pdf/3691/3691399490 70.pdf

Hernández, E., Salazar, M., Vacío, M. A. y Rodríguez, S. (2017). Instrumento para evaluar la intención de niños mexicanos para consumir bebidas alcohólicas desde la Teoría de la Conducta Planeada. Universitas Psychologica, 16(2), 1-10. Recuperado de https://doi.org/10.11144/Javeriana.upsy162.iein.

Ocaña Zúñiga, J., García Lara, G.A., Cruz Pérez, Ó. y Pérez Jiménez, C.E. (2020). Actitudes hacia el consumo de alcohol en adolescentes chiapanecos. Enseñanza e Investigación en Psicología, 2(1), 84-96. Recuperado de: https://www.revistacneip.org/index.php/cneip/a rticle/view/92/72

Orellana Fierro, M. F. (2019). Percepción del riesgo y recursos de afrontamiento ante el consumo de alcohol y otras drogas en niños de 9 a 11 años. Universidad de Guayaquil: Colombia. Recuperado de http://repositorio.ug.edu.ec/handle/redug/43622
Philips Howards, P. A., Bellis, M. A., Briant, L. B., Jones, H., Downing, J., Kelly, I. E., Bird, T. y Cook, P. A. (2010). Wellbing, alcohol use and sexual activity in young teenagers: findings from a cross-sectional survey in school children in North West England. Substance Abuse Treatment, Prevention and Policy, 5, 27-35. Disponible en https://www.ncbi.nlm.nih.gov/pubmed/2106756 2

Pilatti, A., Godoy, J. y Brussino, S. (2011). Expectativas hacia el alcohol y consumo de alcohol en niños y adolescentes de Argentina. International Journal of Psychology and Psychological Therapy, 11, 13-32. Recuperado de:

https://www.ijpsy.com/volumen11/num1/280/e xpectativas-hacia-el-alcohol-y-consumo-ES.pdf

Rojas Valero, M. J. y Rodríguez Chacón, A. B. (2013). Abuso de drogas en adolescentes y jóvenes y vulnerabilidad familiar. Oficina de las Naciones Unidas Contra la Droga y el Delito (UNODC). Recuperado de https://www.unodc.org/documents/peruandecua dor/Publicaciones/Publicaciones2014/LIBRO_ ADOLESCENTES_SPAs_UNODCCEDRO.pdf

Rojas Valero, M. J., Rodríguez Chacón, A. B., Zereceda Gygax, J. y Otiniano Campos, F. (2013). Abuso de drogas en adolescentes y jóvenes y vulnerabilidad familiar. Oficina de las Naciones Unidas Contra la Droga y el Delito (UNODC). Disponible en https://www.unodc.org/documents/peruandecua dor/Publicaciones/Publicaciones2014/LIBRO_ ADOLESCENTES_SPAs_UNODCCEDRO.pdf.

Secretaria de Salud. (2014). Reglamento de la ley general de salud en materia de investigación para la salud. Recuperado de http://www.salud.gob.mx/unidades/cdi/nom/co mpi/rlgsmis.html

The Family Watch, (2017). Consumo de alcohol en menores y sus implicaciones en la Familia. Disponible https://www.thefamilywatch.org/wpcontent/uploads/informe-alcohol_def.pdf 
Villatoro Velázquez, J. A., Mora Icaza, M. E. M., Del Campo Sánchez, R. M., Fregoso Ito, D. A., Bustos Gamiño, M. N., Resendiz Escobar, E., Mujica Salazar, R., Bretón Cirett, M., Soto Hernández, I. S. y Cuñas Martínez, V. (2016). El consumo de drogas en estudiantes de México: tendencias y magnitud del problema. En Salud Mental, 39(4), 193-203. Recuperado de http://www.scielo.org.mx/scielo.php?script=sci _arttext\&pid=S0185-33252016000400193 